\title{
Perforation of the left atrium and aortic bulb two years after percutaneous closure of atrial septal defect
}

Perforacja lewego przedsionka oraz opuszki aorty dwa lata po przezskórnym zamknięciu ubytku w przegrodzie międzyprzedsionkowej

\section{Adrian Stankiewicz', Krzysztof Matlak', Grzegorz Juszczyk', Adam Sewastianowicz', Sławomir Dobrzycki², Bogusław Poniatowski², Tomasz Hirnle ${ }^{1}$}

1Department of Cardiac Surgery, Medical University of Bialystok, Poland

2Department of Invasive Cardiology, Medical University of Bialystok, Poland

Post Kardiol Interw 2011; 7, 4 (26): 320-322

DOI: $10.5114 /$ pwki.2011.25793

\begin{abstract}
Non-surgical closure of the atrial septal defect (ASD) is an effective and safe method of treatment and major complications are rare. The paper reported a case of female with ischaemic heart disease, 2 years after percutaneous closure of atrial septal defect using CARDIA Closure Device. She was admitted to the Department of Cardiac Surgery for CABG procedure. During operation we found perforation of the left atrium and aortic bulb caused by the CARDIA Closure Device's arms. This changed the extent of the planned procedure and forced the surgeon to perform an extensive, atypical heart operation finally complicated by death. Based on presented case, we believe that indications for coronary angiography before planned percutaneous ASD should be extended. Patients with an implanted occluder who require heart surgery for any reasons should undergo a computed tomography or magnetic resonance imaging scan to assess all artificial devices and their relation to anatomical structures and heart chambers.
\end{abstract}

Key words: atrial septal defect, ischaemic heart disease, intraaortic balloon pump

\section{Streszczenie}

Nieoperacyjne zamykanie ubytku w przegrodzie międzyprzedsionkowej (ang. atrial septal defect, ASD) uważa się za skuteczną i bezpieczną metodę leczenia, a istotne powikłania zdarzają się rzadko. Przedmiotem doniesienia jest przypadek pacjentki z chorobą wieńcową, 2 lata po przezskórnym zamknięciu ASD systemem CARDIA, przyjętej do Kliniki Kardiochirurgii w celu wykonania operacji pomostowania aortalno-wieńcowego. Śródoperacyjnie stwierdzono perforację lewego przedsionka oraz opuszki aorty przez ramiona systemu CARDIA. Z tego powodu konieczna była zmiana zakresu planowanego zabiegu i wykonanie rozległej, nietypowej operacji serca, która była powikłana zgonem. Na podstawie opisanego przypadku autorzy uważają, że należy poszerzyć wskazania do koronarografii przed planowanym przezskórnym zamknięciem ASD. U chorych z wszczepionym okluderem, u których wystąpi konieczność operacji serca z innych powodów, należy wykonać badania metodą tomografii komputerowej lub rezonansu magnetycznego w celu uwidocznienia wszystkich sztucznych elementów i ich relacji do struktur anatomicznych i jam serca.

Słowa kluczowe: ubytek w przegrodzie międzyprzedsionkowej, choroba wieńcowa, balon do kontrapulsacji wewnątrzaortalnej

\section{Case report}

A 53-year-old female with ischaemic heart disease who initially presented with an acute coronary syndrome (ACS) treated conservatively was referred to the Department of Cardiosurgery of the University Clinical Hospital 1 month later for coronary artery bypass graft (CABG) operation.
The following coexisting diseases were found: diabetes mellitus type 2 treated with insulin for the last 13 years, hypertension, mixed hypercholesterolaemia with high LDL values, obesity. Two years before the patient underwent a percutaneous closure of the atrial septal defect (ASD) in the form of persistent foramen ovale (PFO) with the $28 \mathrm{~mm}$ CARDIA ASD Closure Device. She had a normal ejection 
fraction (EF) before the procedure and did not have coronary angiography. Transoesophageal echocardiography (TEE) showed successful closure of the defect with a trace of residual flow across the interatrial septum (IAS).

\section{Preoperative diagnostics}

Coronary angiography performed due to ACS disclosed the presence of multivessel coronary artery disease: massive atherosclerotic changes over the full length of the left anterior descending artery (LAD) with the presence of calcifications narrowing the artery lumen by $80-90 \%$ in the proximal segment and by $99 \%$ in the middle segment with TIMI flow 2. Diagonal branches: atherosclerotic changes at full length of the vessels. Circumflex artery (CX) atherosclerotic changes at full length of the artery with a proximal constellation of changes narrowing the lumen up to $80 \%$. Right coronary artery (RCA) with a constellation of atherosclerotic changes causing up to $90 \%$ stenosis in the middle part. The artery responsible for ACS was not identified. Ventriculography demonstrated akinesis of the anterior wall and the apex, hypokinesis of the basal inferior segment, ejection fraction (EF) $-35 \%$. The flow in the carotid and iliac arteries was not assessed. Transthoracic echocardiography showed significant ischaemic mitral valve regurgitation with a $2 / 3+$ regurgitant flow, vena contracta $7 \mathrm{~mm}$, left atrial diameter in the $\mathrm{M}$-mode presentation of $4.8 \mathrm{~cm}$ and of $6.9 \mathrm{~cm} \times 5.5 \mathrm{~cm}$ in the 4 -chamber (4C) presentation. There was significant tricuspid regurgitation with severe pulmonary hypertension, 3+ regurgitant flow, maximal gradient of the regurgitant flow of $70 \mathrm{mmHg}$. Tricuspid annulus was markedly enlarged to $4.4 \mathrm{~cm}$, right atrium (4C) $7.1 \mathrm{~cm} \times 5.1 \mathrm{~cm}$, right ventricle (M-mode) $4.6 \mathrm{~cm}$. There was a globally decreased left ventricular (LV) ejection fraction of $37 \%$ with dyskinesis of the apical inferior and lateral segments and akinesis of the apex, apical septal and other anterior segments of the LV. Additionally a turbulent flow was present at the site of ASD closure 2 years before. Initial qualification for isolated CABG was supplemented after the above examinations by qualification for mitral and tricuspid valve valvuloplasty.

\section{Technique of the operation}

Under general anaesthesia, after central sternotomy, the pericardial sac was opened, demonstrating an enlarged and badly contracting heart. Material for the CABG was taken (left internal mammary artery - LIMA and a fragment of the saphenous vein - SV). Extracorporeal circulation (ECC) was initiated. After removal of the blood from the heart, during surgical preparation of the access to the left atrium with the Guirardon method it became visible that one of the CARDIA device arms punctured the left atrial roof. The aorta was clamped and cold-blood cardioplegia was administered into the aortic bulb. A leak of the cardioplegia from the left aortic sinus caused by the penetration of the next CARDIA device arm into the aortic bulb was noted (Figure 1). The CARDIA system was removed. The aorta was dissected and the puncture was closed with Prolene 4/0 sutures on Teflon cushions. An angiographic picture of very narrow coronary arteries with massive atherosclerotic changes up to the distal segments was confirmed. A sequential SV bypass was sewn into the posterior descending artery of the right coronary artery through the second marginal branch of the left coronary artery. A LIMA was implanted into the left anterior descending artery. Mitral valve valvuloplasty was performed with implantation of the Edwards Lifesciences Physio $28 \mathrm{~mm}$ ring. The left atrial roof was reconstructed and a Dacron patch was sewn into the site of the resected IAS. Tricuspid valve valvuloplasty was done (Edwards Lifesciences Calssic 32 ring). During reperfusion a proximal anastomosis of the sequential venous graft was made and the right atrium was closed. A ECC was was discontinued. A control intraoperative TEE demonstrated a good effect of the mitral and tricuspid valve valvuloplasty and the lack of flow through the IAS. Due to increasing symptoms of low cardiac output syndrome, catecholamines were administered and an intraaortic balloon was implanted through the access in the left femoral artery. An extensive, atypical operation which required 267 min of extracorporeal circulation including 189 min of heart ischaemia (aortic clamping) was performed. The extent and time of the procedure increased the intraprocedural bleeding and prolonged haemostasis.

\section{Postoperative course}

Postoperative course was troublesome. Continuous haemodialysis due to renal failure was used in the postoperative care. There was hyperbilirubinaemia with

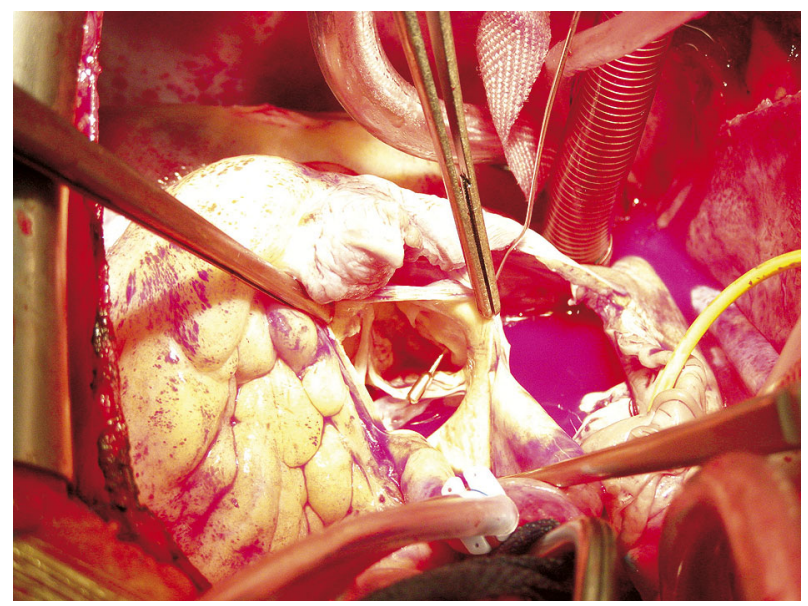

Fig. 1. Intraoperative view. The coronary probe indicates the perforation of the aortic bulb caused by the CARDIA Closure Device

Ryc. 1. Widok śródoperacyjny. Sonda wieńcowa wskazuje miejsce perforacji opuszki aorty przez ramię systemu CARDIA 
maximal bilirubin concentration of $34.4 \mathrm{mg} / \mathrm{dl}$, high activity of transminotransferases and anaemia with thrombocytopenia. Ischaemia of the left lower limb was noted on day 4 after the operation. Revision of the groin in the operating room confirmed the central position of the IABP sheath correctly inserted into the left superficial femoral artery. Normal inflow and backward flow were observed after removal of the IABP. Embolectomy using a Fogarty catheter did not reveal the presence of thrombotic material. It was noted that the left superficial femoral artery was closed in Hunter's canal. The IABP was introduced through the right femoral artery and removed on day 7 after haemodynamic stabilization. The left lower limb was amputated at the level of the lower one third of the thigh 2 weeks later due to the presence of irreversible ischaemic changes. Relevant circulatory stabilization, diuresis return and improvement of the respiratory parameters of mechanical ventilation were obtained in the next days of hospitalization. On day 36 after the operation the patient was transferred to the intensive-care unit (ICU) of the regional hospital in a stable circulatory condition on noradrenaline infusion with continuous mechanical ventilation ( $\mathrm{SIMV}$ with $\mathrm{FiO}_{2}$ 0.35) without sedation but with difficult contact. However, no further improvement of clinical condition was observed and the patient died.

\section{Discussion}

Currently there are no recommendations indicating the need of coronary angiography in adult patients with ASD undergoing percutaneous treatment. Numerous publications show that non-surgical closure of the ASD is an effective and safe method [1-4]. Longstanding experience in the surgical treatment of congenital heart diseases, including ASD, led to construction of guidelines, which indicate that every surgery should be preceded by coronary angiography to search for stenoses of the coronary arteries and treat them simultaneously with coronary artery bypass grafting. This strategy should prevent unexpected periprocedural myocardial infarctions. Coronary angiography should be performed in men over 40 years of age, in women in the menopausal period and in patients with symptoms and risk factors of coronary artery disease [5]. Percutaneous ASD closure is performed in the centres with a possibility of emergency heart surgery. Therefore one should ask whether patients referred for this kind of procedure should be prepared in the same way as patients referred for surgery in terms of coronary artery disease assessment.

The presented patient would have undergone coronary angiography 2 years earlier. The presence of asymptomatic stenoses (diabetes) at this time was probable, which could have changed the qualification for treatment. Perhaps more widespread use of coronary angiography before percutaneous ASD closure should be considered. It seems that this strategy should be addressed to patients meeting the criteria for coronary angiography before planned surgery of the valvular disease.

Another problem which surprised the surgeon in the described case was an intra-operative finding of LA roof and left coronary sinus perforation caused by the arms of the CARDIA occluder. This fact changed the extent of the planned procedure and forced the surgeon to perform an extensive, atypical and therefore long-lasting heart operation. This influenced the occurrence of the postoperative heart failure which required IABP complicated by lower left limb ischaemia and amputation and finally death.

In summary of the problems which occurred in the presented case, we postulate extending the indications for coronary angiography before planned percutaneous ASD closure similarly to valvular diseases referred for surgery. Secondly, patients with an implanted occluder who require heart surgery due to other reasons should undergo a computed tomography or magnetic resonance imaging scan to assess all artificial devices and their relation to anatomical structures and heart chambers. This knowledge would help to avoid intraoperative diagnostics, significantly reduce the operation time and probably limit the postoperative complications.

\section{References}

1. Lesiak M, Witkowski A, Maciejewski P. Interventional cardiology how we treated patients in 2009. Report of Working Group on Interventional Cardiology of the Polish Cardiac Society. Advances in Interventional Cardiology 2010; 2: 71-76. Post Kardiol Interw 2010; 2: 71-76.

2. Egred M, Andron M, Albouaini K, et al. Percutaneous closure of patent foramen ovale and atrial septal defect: procedure outcome and medium-term follow-up. J Interv Cardiol 2007; 20: 395-401.

3. Demkow M, Rużyłło W, Konka M. Ten-year experience with transcatheter closure of secundum atrial septal defects. Advances in Interventional Cardiology 2007; 4: 184-192.

4. Białkowski J, Szkutnik M, Kusa J, et al. Congenital heart defects in children and adults - new goals for team work. Polish Heart J 2008; 66: 1028-1031.

5. Baumgartner H, Bonhoeffer P, De Groot NM, et al. ESC Guidelines for the management of grown-up congenital heart disease (new version 2010). Eur Heart J 2010; 31: 2915-2957. 